\title{
Museology and employment in the Finnish museum field
}

Kalle Kallio and Tanja Välisalo*

Museology is a discipline still establishing itself. It can currently be studied in five Finnish universities. Museology came to Finland as early as 1969 when Secretary of Museum Affairs Jorma Heinonen from the Finnish Museums Association gave his first course in museology. It took more than a decade before museology gained status as a university subject in 1983, and about the same amount of time for the first professorship in 1998. Little by little, museology has strengthened its position in Finnish universities, but what has happened on the labour market at the same time?

Questions about museology and employment have been especially pertinent in Finland. The Finnish Parliament approved a new museum law, which took effect at the beginning of 2006. According to the new law and museum statute, museology is a prerequisite for a museum director and one other professional if a museum is to qualify for state aid. This statute does not affect those who already work in museums, and therefore the consequences can only be seen in the long term. During the preparation of this legislation, there was also debate about the usefulness of museology, and some museums were very much against it. It appeared as though museology was not a mainstream science at the Finnish museums.

In this article, we approach the relationship between museology and museums in Finland on a practical level. We are interested in the status of museology studies in the museum field, among the museum professionals. We will attempt to find the answer by using statistical data. Our material is from two surveys completed in 2003. One is Museoväki'03, a survey of the educational training, work and opinions of museum workers, conducted by the Finnish Museums Association. The other is a survey carried out by Diaario, the Jyväskylä University Museology Students' Organisation, investigating the employment situation and opinions of the Jyväskylä University graduates who have included museology in their studies (later referred to as the Diaario survey).

The respondent groups differ somewhat between the two surveys, since the Museoväki'03 survey represents the whole spectrum of museum professionals and the Diaario survey concentrates on the former students of a particular university. The Museoväki'03 survey features 725 respondents, while the Diaario survey in- 
cludes 102 respondents, with a response rate of $38 \%$. Only $30(32 \%)$ of the respondents in the Diaario survey worked in the museum field. Due to the differences in the number of respondents, we used the two surveys to complement each other, rather than to make a comparison.

To make the results of these surveys more understandable, it is necessary to briefly introduce the position of museology in the Finnish educational system. Like all university subjects, museology is taught at three levels: basic (25-35 ECTS credits), subject (60-75 credits) and advanced studies (135-155 credits). Studying museology is possible in five Finnish universities: Helsinki, Jyväskylä, Oulu, Tampere and Turku. Advanced studies, such as master's degree level, are only possible at the University of Jyväskylä. However, hardly any students take museology as a major subject, since it is considered to best fill its purpose as a minor subject for historians, art historians, etc. Consequently, for the respondents of the two surveys, the possible studies in museology are minor subject studies.

The respondents' average age in Museoväki'03 was 43 years and in the Diaario survey a notably lower 34 years. The explanation comes from noting that it has been possible to study museology since 1983, when the University of Jyväskylä was the first university in Finland to begin teaching this subject. Museoväki'03 also includes older generations. Not surprisingly, women account for the vast majority in both surveys: in Museoväki'03, they represented $78 \%$ and in the Diaario survey, $86 \%$ of the respondents.

The difference in the average age is also perceivable in employment situations of these two respondent groups. As many as $74 \%$ of the museum workers in Museoväki'03 had perma- nent employment. In the Diaario survey, a little over one third $(36 \%)$ were in permanent jobs and, out of those working as museum professionals, this amounted to $53 \%$. The latter percentage cannot be considered completely reliable due to the small number of respondents, but unemployment and short-term employment are due to the young age. In the Museoväki'03 survey, only $31 \%$ of museum workers under the age of 30 were in permanent employment.

Almost $40 \%$ of the Diaario respondents were not in regular employment, but of these the largest single category - $11 \%$ - were unemployed. The low employment rate clearly shows there is not enough work in the museums for all museologists. Even though we cannot assume that all those who studied museology seek employment in the museum field, we do believe that museology must begin and continue serving other fields of employment as well.

\section{MusEOLOGY IN FinNISH MUSEUMS FROM THE 1970S TO THE 21ST CENTURY}

Before the teaching of museology began at the University of Jyväskylä in 1983, museums had to recruit workers who had very little, if any, knowledge about museums and their principles. For instance, the University of Helsinki organized special museum courses in the 1970s, but they were rather brief and did not reach everybody. Learning by doing was almost the only way to become a museum professional.

When the Museoväki'03 survey was planned in 2003, the Finnish Museums Association wanted to find out, among other things, what the state of museology within the museums actually was. The new museum law was still being 
prepared. According to this survey, $47 \%$ of museum professionals with an academic degree have not studied museology at all. About every fourth (24\%) professional, mainly in the older group, has passed a museum course that was specially organized in the 1970s. Almost as many $(26 \%)$ have basic studies in museology and $3 \%$ have subject studies.

The development of museology can easily be seen from the 725 answers to the Museoväki'03 survey. If informants are categorized by the decade in which they came to work in the museum profession, it is quite natural that only $7 \%$ of those museum professionals who have an academic degree, and who started to work before 1981, have studied museology (at least basic studies). The questionnaire did not show it, but presumably these exceptional professionals studied museology in addition to their work in the 1980s and 1990s.

Museology made its breakthrough quite rapidly in Finland in the 1980s. According to the Museoväki'03 survey, 29\% of academic museum professionals who started work in the 1980s had studied at least 25 credits of museology. In the 1990s, this percentage was already $40 \%$, but during the first decade of the 21 st century, it still remained 39\%. Since the year 2000 , about $5 \%$ of new professionals have studied at least 60 credits of museology.

Those who have studied museology are only one part of the question. There have always been professionals who have entered the business without any courses on museum studies. Those who have an academic degree and worked at the Finnish museums before the 1970s almost $60 \%$ - did not study museology or its early counterparts, so-called museum courses. The percentage started to go down in the 1970 s and $51 \%$ of that generation did not have any education in museum studies. In the

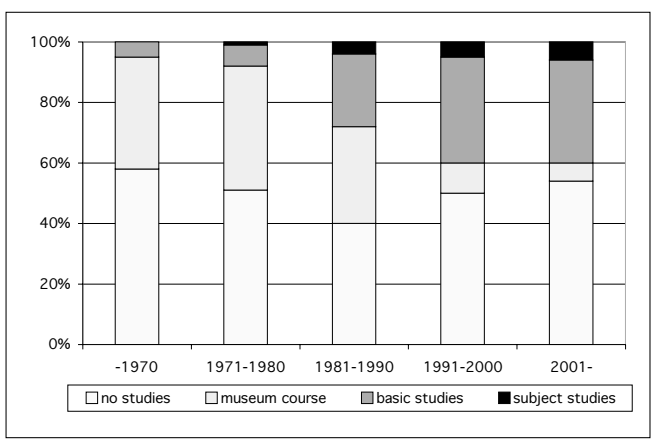

Studies in museology among Finnish museum professionals. This figure describes education in museology. It includes museum professionals who have an academic degree. They are divided by the decades in which they started to work at the museums. Kalle Kallio, Finnish Museums Association 2003.

1980 s, this percentage went down to as low as $39 \%$, but in the $1990 \mathrm{~s}$, numbers seemed to rise. In the 1990s, $50 \%$ of the new museum professionals did not study museology, and in the 21 st century, their share has risen to $55 \%$.

What can we say about such results? First of all, it is quite evident that museology as an academic discipline has increased the volume and depth of university training for museum professionals. Those who have studied museology in the 21st-century universities are better equipped for their working lives than their colleagues 30 years ago. Students of museology can see the social meaning and richness of their work. Museology does not necessarily help in every practical problem, but it is very important for motivation and theoretical thinking.

On the other hand, however, museology only seems to have replaced the old museum courses with better teaching and scientific approaches. Museums still recruit many new workers who have studied at university without museology as part of their curriculum. In fact, 
92 it even appears that their share has increased from the 1980s. There can be several reasons for this phenomenon. Because the survey was carried out in 2003, it does not say anything about those who have left the museum profession since then. If museology is good for motivation, it is possible that those who did not study it were more eager to try a new career somewhere else. And those who stayed have perhaps taken their courses in museology in addition to their work - and hopefully those who start now will do the same in the future, which makes these comparisons very difficult. These reasons might explain why those who started work in the 1980s seem better educated than their counterparts in the 1990s. But there are other reasons, too.

Museum work has changed during the last decades. We have more specialized professionals now than 20 years ago. For instance, those who work with marketing or data systems often have very a different education than traditional museum staff did. Museology might also interest these new professionals, but the situation was probably very different when they were studying. And we still have lots of museum curators who studied art history or ethnology, for instance, in the 1990s, but not museology. If we look at those professionals who were born in the 1970s, who had regular jobs in 2003 (which is not so common at their age) and also university degrees, $60 \%$ of them did not study museology at all, even though they had much better opportunities to do so than their senior colleagues. This situation can be changed in two ways: on the one hand, we need museology to attract more students and, on the other hand, we need further education in museology for those who already work in the museums.

Museology is not a major subject for students of museology in Finland. They study mainly history, ethnology, art history and other majors that are considered useful in the museum world. There are small differences between different majors and museology as a minor subject. If we look at the museum professionals with university degrees, $40 \%$ of those who had ethnology as a major also studied museology as a minor subject (at least basic studies). Students of history were second (32\%), students of art history third (31\%) and archaeology was the last of the so-called traditional museum subjects (15\%). According to the Museoväki'03 survey, those who studied natural sciences did not study museology at all. Approximately $20 \%$ of students of "other majors" studied museology as a minor subject. Studies in museology were extremely rare in museums of natural history, but there were no significant differences between art museums and museums of cultural history.

\section{MUSEOLOGY IN EVERYDAY WORK}

Museology is clearly a discipline for women. According to the Museoväki'03 survey, $61 \%$ of men and $43 \%$ of women with an academic degree did not study museology at all. Basic studies were taken by $32 \%$ of academic women and $21 \%$ of men working in museums. Women studied more museology, regardless of their age or major subject. There are no obvious reasons for this. Women in Finland are nowadays better educated than men, and perhaps also among museum professionals, women study more. If the labour market is unfair for women, studying museology is one way to improve one's prospects.

The Museoväki'03 survey also provides opportunities for looking at the kind of work former students of museology are doing in the 
museums. In general, museology is widely spread among different kinds of professions. Those who work with collections, exhibitions or research studied almost the same amount of museology. Museum educators studied museology most: $44 \%$ of those who say that they spend most of their time in museum education studied at least basic studies in museology (average $29 \%$ ). Those who work in museum administration (23\%) and marketing (21\%) studied museology least.

It is widely debated in the museum field exactly how museology helps museum professionals in their work. In the Museoväki'03 survey, there was a question about the relevance of a person's education to their current job. When the answers were categorized by the studies of museology, the results were extremely interesting. On average, $53 \%$ of those professionals who did not study museology said that their education mainly corresponds to their job. The relevance of education was bound to the studies of museology. Education was mostly relevant for $60 \%$ of those who studied museum courses, $63 \%$ of those who studied at least basic studies in museology and as many as $76 \%$ of those who studied at least subject studies in museology. This is good evidence for museology as a motivator for museum professionals.

Studies of museology were important in many respects. In the Diaario survey, some respondents said that studies of museology turn out to be useful in job interviews and they might also help to negotiate better salaries. But on the other hand, the same respondents listed work experience as the most important factor when trying to get a job. A combination of subjects at university was also considered important, which probably loses its importance after the first vacancies in museums. In Finland, archaeology, art history, ethnology and history are traditionally seen as the only subjects capable of qualifying students for museum work. In 2003 , three quarters $(74 \%)$ of museum professionals had studied one of these subjects as their university major. This phenomenon is declining and museums nowadays presume that their professionals have a university degree in a "suitable" subject without defining it so strictly. However, studies in museology are not yet a standard, for instance in job advertisements.

\section{THE MEANING OF MUSEOLOGY}

How do museum professionals themselves actually experience museology? It seems clear that museology increases contentment with the museum field, whereas academic studies in general do not have the same effect. The majority $(92 \%)$ of the respondents in the Diaario survey felt that museology studies had somehow benefited them. In the questionnaire, they were able to describe the benefits they experienced. The most obvious one was the basis museology offered for museum work. Theoretical tools, such as basic concepts and principles, were familiar when entering working life. Museology studies were also experienced as a source of a professional identity. Some even felt they had a calling for museum work.

Practical knowledge was a benefit brought up by many Diaario respondents. They felt it was "a valuable addition to otherwise theoretical studies". The ability to deal with basic museum tasks was something the respondents especially said that museology had given them. The most practical part of the studies is, of course, the traineeship, which was valued by many respondents. The relationships the respondents established with their co-students and during their traineeship were also conside- 
94 red valuable. There were even mentions of traineeships leading to employment later on.

Among the benefits mentioned above, we find the emphasis on both theoretical and practical features of museology intriguing. Based on the written experiences of the respondents, it seems that the theoretical part took centre stage when museology was viewed from the perspective of museum work. The practical side was emphasized in relation to other subjects.

This is interesting because common criticism of museology is about the theoretical side of the subject. Many museum professionals say that museology is a mere theory without any practical use. They do not criticize history or ethnology, for instance, as a bunch of useless theories, as students of museology do. Somehow it is hard for museum professionals to see that museology is an academic and theoretical discipline like any other science. But it is also encouraging that students see museology as a fresh variety in their curriculum. This is something that museology, as a developing science, should not lose.

According to the Diaario survey, museology was not beneficial for those people working in museums only. Several respondents considered that museology studies had a civilizing effect. Willingness to visit museums and the ability to view exhibitions critically also increased. Some people employed as schoolteachers felt museology benefited them in their current profession.

The Museoväki'03 survey and the Diaario survey both showed that museology studies had positive influences. However, it seems that the position of museology within the museum field is unstable. Half of the new museum professionals have not studied museology, but many of those who did study it have not been able to find work as museum professionals. The difficulty of gaining employment in this field was heavily emphasized by the Diaario respondents. Museology has proved its worth. The new goal is in making the demand and supply meet on the museum labour market.

${ }^{*}$ Kalle Kallio is the director of The Central Museum of Labour.

Address: The Central Museum of Labour, Väinö Linnan aukio 8, 33210 Tampere, Finland

E-mail:kalle.kallio@tkm.fi

Tel: +358-3-2538861

*Tanja Välisalo is a student of museology at the University of Jyväskylä.

Address:

University of Jyväskylä, P.O. Box 35

FI-40014 University of Jyväskylä, Finland

E-mail: tanja.välisalo@mediakajo.fi

The Museoväki'03 survey was reported by Kalle Kallio at the Museo 3/2003 (pp. 8-11, 18-21) and Julius 11/2003 (pp. 9-13) in Finnish. Both are published by The Finnish Museums Association.

The Diaario survey was reported by Virpi Kämäräinen and Tanja Välisalo at the University of Jyväskylä website (http://www.jyu.fi/hum/laitokset/taiku/opiskelu/museologialesittely/sijoittuminen/). 